\title{
Effects of anthropometric measurements on spinal anaesthesia block characteristics and hemodynamics
}

\section{Antropometrik ölçümlerin spinal anestezi blok karakteristiğine ve hemodinamiye etkileri}

\author{
Pınar KARACA BAYSAL ${ }^{1}$, Birzat Emre GÖLBOYU ${ }^{1}$, Mürsel EKINCi ${ }^{1}$, Mahmut GÜDEN², Ali AHISKALioĞLU³ \\ Erkan Cem ÇELIK ${ }^{4}$
}

\begin{abstract}
We aimed to determine the effects of some anthropometric values on sensorial block characteristics of spinal anesthesia and hemodynamics in patients unergoing elective cesarean sections performed under spinal anesthesia. Weight, length, body surface area, and body mass index, abdominal, waist, and hip circumferences of 50 patients were measured. Spinal anesthesia was applied while the patient was sitting erect. The time of sensorial block to reach the T4 level and the maximum sensorial block level were recorded in each case. Cases who developed hypotension and bradycardia during the spinal anesthesia were recorded. In this study hypotension was observed in 54\% of patients and it was determined that the prevalence of hypotension increased in patients with a shorter height, larger abdominal circumference, higher body mass index, lower body surface area and a higher waist/hip ratio. It was found that the prevalence of bradycardia increased in patients with a shorter height, higher body mass index, lower body surface area and a higher waist/hip ratio. This study also determined a positive correlation between the values of height, weight and body surface area and the time of sensorial block to reach the T4 dermatome; and a positive correlation between the body mass index and the dermatome area of the maximum sensorial block In line with the values provided by simple and non-time consuming anthropometric measurements the patients who are planned to receive a spinal anesthesia may be priorly prepared against advers effects of bradycardia and hypotension that may develop, and to estimate the sensorial block characteristics of the spinal anesthesia.
\end{abstract}

Key words: Abdominal circumference, anthropometric measurement, spinal anesthesia, body mass index, body surface area öz

Çalışmamızda, spinal anestezi ile yapılan elektif sezaryen ameliyatına alınacak hastalardaki bazı antropometrik değerlerin spinal anestezinin sensoryal blok karakteristiğine ve hemodinamiye olan etkilerini saptamayı amaçladık. Operasyon öncesi 50 hastanın ağırlıkları tartılıp, boyları ölçülerek vücut yüzey alanı ve vücut kitle indeksleri hesaplandı. Bunun yanında abdominal, bel ve kalça çevrelerinin uygun anatomik noktalardan ölçümü yapıldı ve kaydedildi. Oturur pozisyonda spinal anestezi uygulandı. Duyusal bloğun T4 seviyesine ulaşma zamanı, maksimum duyusal blok seviyesi her vakada kaydedildi. Spinal anestezi süresince hipotansiyon ve bradikardi gelişen vakalar kaydedildi. Çalışmada hastaların \%54'ünde hipotansiyon görülürken, kısa boy, geniş abdominal çevre, yüksek vücut kitle indeksi, düşük vücut yüzey alanı ve yüksek bel/kalça oranları olan hastalarda hipotansiyon görülme sıklığının arttığı görüldü. Hastaların \%18'inde bradikardi gelişirken kısa boy, yüksek vücut kitle indeksi, düşük vücut yüzey alanı ve yüksek bel/kalça oranları olan hastalarda bradikardi görülme sıklığının arttığını saptadık. Ayrıca çalışmada, boy, kilo ve vücut yüzey alanı değerleriyle sensöryel bloğun T4 dermatomuna ulaşma süresi arasında pozitif korelasyon saptanırken, vücut kitle indeksi ile maksimum sensöryal bloğun oluştuğu dermatom sahası arasında pozitif korelasyon olduğunu saptandı. Ayrıca vücut kitle indeksi ve bel/kalça oranı ile efedrin gereksinimi arasında da pozitif korelasyon saptandı. Spinal aneztezi uygulaması planlanan hastalarda yapılacak basit ve zaman almayan antropometrik ölçümlerin vereceği değerlerler doğrultusunda gelişebilecek olası bradikardi ve hipotansiyon durumlarına karşı daha hazırlıkı olunabilir, spinal anestezi duysal blok karakteristiği hakkında tahmin yürütülebilir.

Anahtar kelimeler: Abdominal çevre, antropometrik ölçüm, spinal anestezi, vücut kitle indeksi, vücut yüzey alanı

Received: 22.12 .2015

Accepted: 04.02.2016

${ }^{1}$ Department of Anesthesia, Kars State Hospital

${ }^{2}$ Department of Gynecology and Obstetric, Kars State Hospital

${ }^{3}$ Department of Anesthesia, Atatürk University

${ }^{4}$ Department of Anesthesia, Palandöken State Hospital

Yazışma adresi: Pınar Karaca Baysal, Department of Anesthesia, Kars State Hospital, Kars

e-mail: drpinarkaraca@hotmail.com 


\section{INTRODUCTION}

When selecting the anaesthesia method in caesarean operations, attention must be paid to the urgency of the operation, pre-existing maternal systemic problems, general status of the fetus, and the surgeon's and patient's preference. Although general or regional anaesthesia can be used in caesarean operations, regional anaesthesia is the most widely preferred anaesthesia method for caesarean sections in developed countries. Regional anaesthesia offers many advantages to the mother as follows: mother is awake during the labour, very little or no requirement for airway intervention, protection of airway reflexes, reduced blood loss, reduced probability of drug-related fetal depression, and the continuation of analgesia in the postoperative period ${ }^{1,2}$.

One of the most frequently used regional anaesthesia techniques is spinal anaesthesia, in which nerve transmission is temporarily halted with the injection of local anaesthetic into the cerebral spinal fluid ${ }^{3}$.

As there is a greater amount of epidural fat tissue in obese patients, the epidural veins are widened and the epidural space is narrowed. Therefore, there is a need for $20-25 \%$ less local anaesthetic in spinal and epidural anaesthesia. In circumstances that lead to an increase in intra-abdominal pressure or widening of the epidural veins, unwantedly higher levels of block are induced. A high level of block easily causes respiratory depression. Pregnant patients display higher sensitivity to local anaesthetics during regional anaesthesia and the dosage requirement can be reduced down to $30 \%$. Neural blockage forms at low concentrations of local anaesthetics ${ }^{4}$.

With increasing rates of maternal obesity and the accompanying comorbidities throughout the world, maternal obesity has been reported to be a significant public health problem ${ }^{5}$. Maternal obesity is accepted as a factor which increases the risk of complications during pregnancy and the labor, including stillbirth, childhood obesity and diabetes ${ }^{6}$. In the United Kingdom, it is recommended that anthropo- metric measurements should be performed for all pregnant women because of the negative effects of obesity on the health of both mother and her child?. In the last 20 years, as in developed countries, there has been an increase in socio-economic conditions and alteration of the nutritional habits in Turkey which resulted in an increase in the rates of obesity. The main reason that obesity is seen more often in females is excessive weight gain before and during pregnancy ${ }^{8}$.

Taking these changes into consideration, the aim of this study was to determine the effects of calculated values or measurements such as body mass index (BMI), body surface area (BSA), abdominal circumference $(A C)$, and waist:hip ratio on the hemodynamic and sensorial block characteristics of spinal anaesthesia applied to patients undergoing elective caesarean section operations.

\section{MATERIAL and METHODS}

Approval for the study was granted by the local ethics committee. Informed consent was obtained from all the study participants. This prospective, double-blind study was conducted on 50 cases with American Society of Anesthesiologists (ASA) score I-II, who were to undergo elective caesarean operation.

Exclusion criteria included contraindications for spinal anaesthesia (coagulopathy, severe aorta and mitral insufficiency, elevated intracranial pressure, infection, hypovolemia, etc.), refusal of the intervention, presence of peripheral vascular disease, preeclampsia or eclampsia, insufficient amount of amniotic fluid or multiple pregnancies history of allergy to the drugs which were to be used, use of food or drugs known to disrupt the sepsis and coagulation system.

Preoperatively, all the patients were weighed, and their height was measured. BSA (DuBois formula $B S A=$ weight $0.425 \times$ height 0.725$) \times 0.007184)$, and $\mathrm{BMI}$ (body weight/height2) of the patients were calculated. Demographic information and gestational 
weeks of each patient were recorded. With the patient standing upright, AC was measured from the mid-point between the upper part of the iliac bone and the $12^{\text {th }}$ costa and hip circumference was measured from the most prominent part of the gluteal muscles and these measurements were recorded.

In the premedication room, a vascular route was opened on the back of the left hand with a $20 \mathrm{G}$ intracatheter and 20 minutes before the operation an infusion of $0.9 \% \mathrm{NaCl}$ was started at the rate of 10 $\mathrm{ml} / \mathrm{kg} /$ hour. In the operating room, all patients were routinely monitored with 3-lead electrocardiographic (ECG) examination, non-invasive blood pressure (NIBP), and peripheral oxygen saturation $\left(\mathrm{SpO}_{2}\right)$ measurements. With the patient in a sitting position, the subarachnoid space at the L3-L4 space was entered with a 25G Quincke needle and spinal anaesthesia was administered with $10 \mathrm{mg}$ hyperbaric bupivacaine. Following application of the block, the level of the sensory block was evaluated at one-minute intervals with the pinprick test. When the sensory block reached T4 level, the operation was permitted to start. The time taken to reach T4 level of sensory block and maximum sensory block level were recorded for each patient.

The measurements of heart rate (bpm), mean arterial pressure (MAP), systolic artery pressure (SAP), and diastolic artery pressure (DAP) were performed and recorded at 1-min intervals until a sufficient block level for surgery was reached, then at 5-min intervals after an adequate block level was achieved.. These measurements were repeated at 15, 30 and 45 mins after the surgical incision preoperatively; and at 5, 15, 30 and 60 mins postoperatively. If the basal SAP fell by more than $20 \%$ or below $90 \mathrm{mmHg}$, it was defined as hypotension. In cases where hypotension developed, $10 \mathrm{mg}$ iv ephedrine $\mathrm{HCl}$ was applied and if heart rate fell below $40 \mathrm{bpm}, 1 \mathrm{mg}$ atropine was given intravenously. A record was made of cases where hypotension and bradycardia developed following the spinal anaesthesia procedure.

Data analysis was performed using SPSS22.0 (IBM
Corporation, Armonk, New York, USA) software. Conformity of the data to normal distribution was tested with the Shapiro-Wilk test and evaluation of variance homogeneity with the Levene test. In the comparison of two independent groups, the Independent Samples t-test together with Bootstrap results was used while the Mann Whitney U-test was used with the Monte Carlo simulation technique. To examine the correlation of variables with each other, the Spearman rho tests were applied. In the comparison of categorical data, the Pearson Chi-square with the Monte Carlo simulation technique was used. Quantitative data were stated as mean \pm standard deviation (SD), median \pm interquartile range (IQR) and median range (minimum-maximum). Categorical data were stated as number $(\mathrm{n})$ and percentage (\%). Data were examined in a $95 \%$ confidence interval. A value of $p<0.05$ was accepted as statistically significant.

\section{RESULTS}

Demographic data, anthropometric measurements, and spinal anaesthesia sensorial block characteristics of all the cases are shown in Table 1.

The mean time taken after spinal anaesthesia to reach the target sensorial block level of T4 dermatome was determined to be 5 mins. In 2 cases the sensori-

Table 1. Demographic data of the patients, anthropometric measurements and spinal block characteristics.

\begin{tabular}{ll}
\hline Number of patients & 50 \\
Age & $24.5 \pm 4.35$ \\
Height $(\mathrm{cm})$ & $163.9 \pm 7.39$ \\
Weight $(\mathrm{kg})$ & $80.9 \pm 6.3$ \\
Gestational week & $39(39-41)$ \\
Abdominal circumference $(\mathrm{cm})$ & $96.6 \pm 8.6$ \\
Body Mass Index $\left(\mathrm{kg} / \mathrm{m}^{2}\right)$ & $30.1 \pm 2.1$ \\
Body Surface Area $\left(\mathrm{m}^{2}\right)$ & $1.86 \pm 0.1$ \\
Waist:hip ratio & $0.86 \pm 0.21$ \\
Time to reach T4 (mins) & $5(7-3)$ \\
Maximum block level - $\mathrm{n},(\%)$ & \\
T4 & $35(70 \%)$ \\
T3 & $9(18 \%)$ \\
T2 & $4(8 \%)$ \\
T1 & $2(4 \%)$
\end{tabular}

Median Range (Maximum-Minimum), $n$ (\%), mean \pm SD (standard deviation) 
Table 2. Comparisons of patients with and without hypotension.

\begin{tabular}{|c|c|c|c|}
\hline & $\begin{array}{c}\text { No hypotension } \\
\text { n (\%) } \\
23(46 \%)\end{array}$ & $\begin{array}{c}\text { Hypotension } \\
\text { n (\%) } \\
27(54 \%)\end{array}$ & $\mathbf{p}$ \\
\hline Age & $25.43 \pm 4.61$ & $23.74 \pm 4.04$ & 0.173 \\
\hline Height (cm) & $167.48 \pm 6.55$ & $160.89 \pm 6.78$ & 0.005 \\
\hline Weight (kg) & $82.43 \pm 6.16$ & $79.63 \pm 6.32$ & 0.118 \\
\hline Gestational week & $39(39-41)$ & $39(39-41)$ & 0.752 \\
\hline Abdominal circumference $(\mathrm{cm})$ & $89.52 \pm 5.20$ & $102.74 \pm 5.81$ & $<0.001$ \\
\hline Body Mass Index $\left(\mathrm{kg} / \mathrm{m}^{2}\right)$ & $29.32 \pm 2.36$ & $30.81 \pm 2.65$ & 0.033 \\
\hline Body Surface Area $\left(\mathrm{m}^{2}\right)$ & $1.91 \pm 0.10$ & $1.83 \pm 0.10$ & 0.007 \\
\hline Waist: hip ratio & $0.79 \pm 0.26$ & $0.88 \pm 0.10$ & 0.014 \\
\hline Time to reach T4 (mins) & $6(7-4)$ & $5(6-3)$ & $<0.001$ \\
\hline \multicolumn{4}{|l|}{ Maximum block level - n, (\%) } \\
\hline T4 & $21(91,3 \%)$ & $14(51,8 \%)$ & \\
\hline T3 & $0(0 \%)$ & $9(33.3 \%)$ & \\
\hline $\mathrm{T} 2$ & $2(8.7 \%)$ & $2(7.4 \%)$ & $<0.001$ \\
\hline $\mathrm{T} 1$ & $0(0 \%)$ & $2(7.4 \%)$ & \\
\hline
\end{tabular}

Independent T test - Mann Whitney U Test - Pearson Chi-Square Test

Median Range (Maximum-Minimum), $n(\%)$, Mean $\pm S D$ (standard deviation)

Table 3. Comparisons of patients with and without bradycardia.

\begin{tabular}{|c|c|c|c|}
\hline & $\begin{array}{c}\text { No bradycardia } \\
\text { n (\%) } \\
41(82 \%)\end{array}$ & $\begin{array}{c}\text { Bradycardia } \\
\text { n (\%) } \\
9(18 \%)\end{array}$ & $\mathbf{p}$ \\
\hline Age & $25.07 \pm 3.7$ & $22 \pm 6.1$ & 0.54 \\
\hline Height (cm) & $165.4 \pm 6.8$ & $156.8 \pm 5.5$ & $<0.001$ \\
\hline Weight (kg) & $81.5 \pm 6.4$ & $77.8 \pm 5$ & 0.114 \\
\hline Gestational week & $39(39-41)$ & $39(39-41)$ & 0.532 \\
\hline Abdominal circumference $(\mathrm{cm})$ & $96 \pm 8.4$ & $99.6 \pm 9.4$ & 0.252 \\
\hline Body Mass Index $\left(\mathrm{kg} / \mathrm{m}^{2}\right)$ & $28.7 \pm 2.53$ & $31.70 \pm 2.47$ & 0.043 \\
\hline Body Surface Area $\left(\mathrm{m}^{2}\right)$ & $1.88 \pm 0.1$ & $1.78 \pm 0.07$ & 0.005 \\
\hline Waist:hip ratio & $0.81 \pm 0.12$ & $0.87 \pm 1.1$ & 0.038 \\
\hline Time to reach T4 (mins) & $6(7-4)$ & $5(6-3)$ & $<0.001$ \\
\hline \multicolumn{4}{|l|}{ Maximum block level - n, (\%) } \\
\hline T4 & $35(85,3 \%)$ & $0(0 \%)$ & \\
\hline T3 & $6(14.6 \%)$ & $3(33.3 \%)$ & \\
\hline $\mathrm{T} 2$ & $0(0 \%)$ & $4(44.4 \%)$ & $<0.001$ \\
\hline $\mathrm{T} 1$ & $0(0 \%)$ & $2(22.2 \%)$ & \\
\hline
\end{tabular}

Independent T test - Mann Whitney U Test - Pearson Chi-Square Test

Median Range (Maximum-Minimum), n (\%), Mean \pm SD (standard deviation)

al block was at T1 level. The level of sensorial block mostly observed was T4 in 35 cases (Table 1 ).

Hypotension was observed in $54 \%$ of the pregnant cases in the study. A statistically significant difference was determined in the height, $\mathrm{AC}, \mathrm{BMI}, \mathrm{BSA}$, and waist:hip ratio values of the cases who developed hypotension. A statistically significant difference was determined between two groups regarding the time elapsed to reach T4 dermatome which was the desired level for minimum pain during the surgical proce- dures of caesarean operations where the maximum sensorial block was achieved (Table 2).

Bradycardia was observed to develop in $18 \%$ of the pregnant cases in the study. A statistically significant difference was determined in the height, BMI, BSA, and waist:hip ratio values of the cases who developed bradycardia $(p<0.05)$. A statistically significant difference was determined between two groups regarding the time required to reach $\mathrm{T} 4$ dermatome which was the desired level for minimum pain du- 
ring the surgical procedures of caesarean operations, where the maximum sensorial block was achieved $(p<0.05)$ (Table 3).

As a result of the correlation analysis made between the anthropometric measurements and the time taken for the sensorial block to reach the T4 dermatome, a statisically significant and very advanced level of positive correlation was determined between height and BSA and the time for the sensorial block to reach T4 dermatome $(p<0.001)$. A negative correlation was determined at a statistically high level between $\mathrm{BMI}, \mathrm{AC}$, and the waist:hip ratio and the time of the sensorial block to reach T4 dermatome $(p<0.001)$. A statistically positive correlation was determined between weight and the time of the sensorial block to reach T6 dermatome $(p<0.05)$. No statistically significant correlation was determined between age and the time of the sensorial block to reach T4 dermatome (Table 4) (Figure 1).

When the correlation was examined between ant-

Table 4. Correlations between anthropometric measurements and the time taken for the sensorial block to reach T4 dermatome.

\begin{tabular}{lll}
\hline & \multicolumn{1}{c}{$\mathbf{r}$} & $\mathbf{p}$ value \\
\hline Age & 0,170 & 0,238 \\
Height $(\mathrm{cm})$ &, $620^{* *}$ & 0,000 \\
Weight $(\mathrm{kg})$ &, $347^{*}$ & 0,014 \\
Body Mass Index $\left(\mathrm{kg} / \mathrm{m}^{2}\right)$ &,$- 503^{* *}$ & 0,000 \\
Body Surface Area $\left(\mathrm{m}^{2}\right)$ &, $563^{* *}$ & 0,000 \\
Abdominal Circumference $(\mathrm{cm})$ &,$- 503^{* *}$ & 0,000 \\
Waist: hip Ratio &,$- 589^{* *}$ & 0,000 \\
\hline
\end{tabular}

Spearman's rho Test r:correlation coefficient ${ }^{* *} p<0.01,{ }^{*} p<0.05$ hropometric measurements and the dermatome site where the maximum sensorial block was formed, a statistically significant positive correlation was determined between $A C$ and the dermatome site where the maximum sensorial block was formed $(p<0.05)$. A statistically significant positive correlation at a high level was determined between $\mathrm{BMI}$ and the dermatome site where the maximum sensorial block was formed $(p<0.001)$. A statistically significant positive correlation at a high level was determined between weight and the dermatome site where the maximum sensorial block was formed $(p<0.01)$. A statistically significant negative correlation at a high level was determined between height, BSA, and the waist:hip ratio and the dermatome site where the maximum sensorial block was formed $(p<0.001)$ (Table 5) (Figure 2).

When the correlation was examined between anthropometric measurements and the requirement for ephedrine, a statistically significant positive correlation was determined between abdominal circumference and the requirement for ephedrine $(p<0.05)$. A

Table 5. Correlations between the anthropometric measurements and the dermatome site where the maximum sensorial block was formed.

\begin{tabular}{lll}
\hline & \multicolumn{1}{c}{$r$} & p value \\
\hline Age & -.16 & 0.254 \\
Height $(\mathrm{cm})$ & $-.737^{* *}$ & 0.000 \\
Weight $(\mathrm{kg})$ & $-.420^{* *}$ & 0.002 \\
Body Mass Index $\left(\mathrm{kg} / \mathrm{m}^{2}\right)$ & $.507^{* *}$ & 0.000 \\
Body Surface Area $\left(\mathrm{m}^{2}\right)$ & $-.680^{* *}$ & 0.000 \\
Abdominal Circumference $(\mathrm{cm})$ & $.311^{*}$ & 0.028 \\
Waist: hip Ratio & $-.656^{* *}$ & 0.000 \\
\hline
\end{tabular}

Spearman's rho Test r: Correlation Coefficient ${ }^{*} p<0.01,{ }^{*} p<0.05$
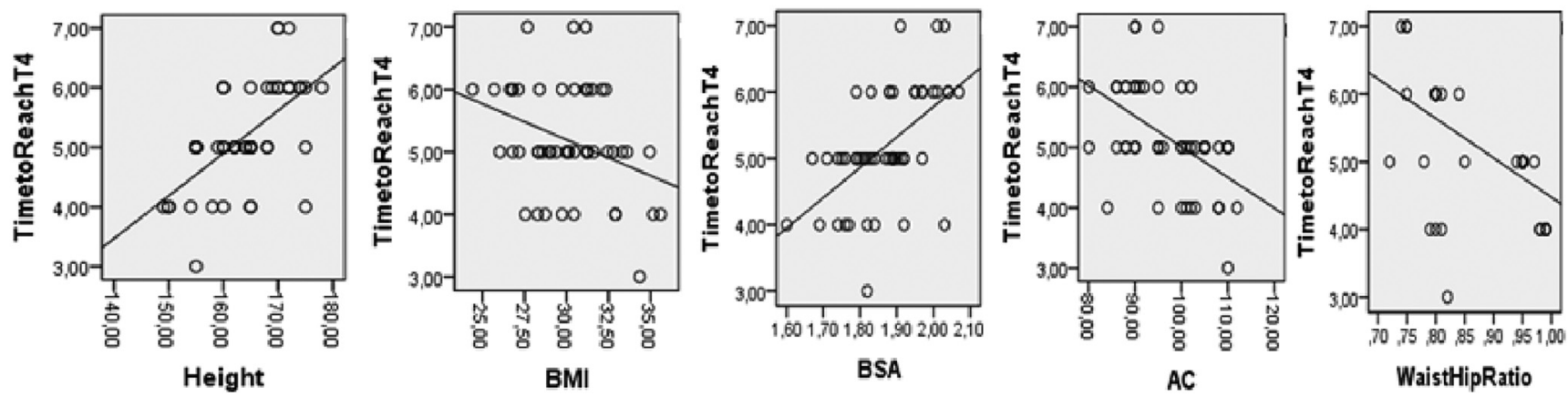

Figure 1. Correlation between anthropometric measurements and the time taken fort the sensorial block to reach T4 dermatome. 


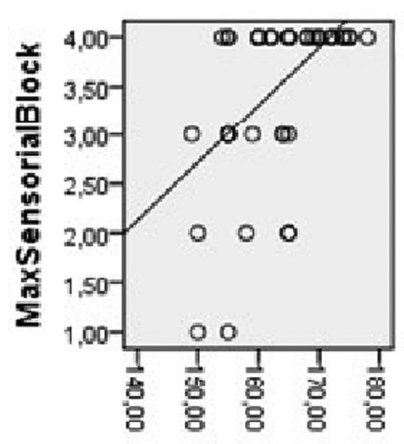

Height

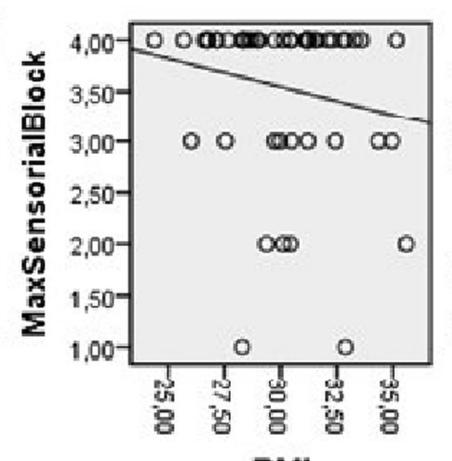

BMI

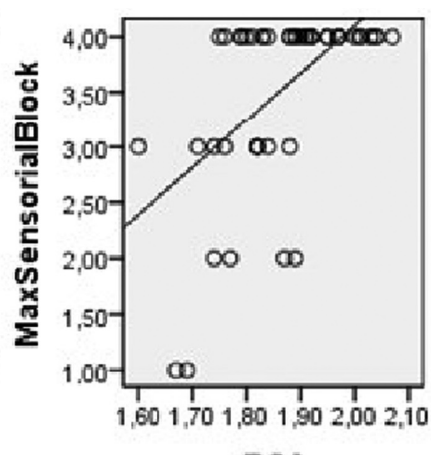

BSA

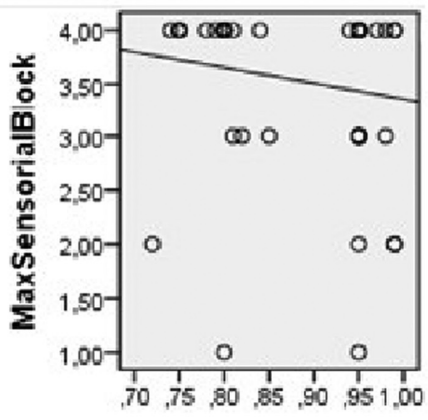

WaisthipRatio

Figure 2. Correlation between anthropometric measurements and the dermatome size where the maximum sensorial block was formed.

statistically significant positive correlation at a high level was determined between BMI and the waist: hip ratio and the requirement for ephedrine $(p<0.001)$. A statistically significant negative correlation at a high level was determined between BSA and height and the requirement for ephedrine $(p<0.01, p<0.001)$. No

Table 6. Correlations between anthropometric measurements and the requireent for ephedrine.

\begin{tabular}{lll}
\hline & \multicolumn{1}{c}{$\mathbf{r}$} & p value \\
\hline Age & -0.169 & 0.241 \\
Height $(\mathrm{cm})$ & $-.542^{* *}$ & 0.000 \\
Weight $(\mathrm{kg})$ & -0.218 & 0.128 \\
Body Mass Index $\left(\mathrm{kg} / \mathrm{m}^{2}\right)$ & $.767^{* *}$ & 0.000 \\
Body Surface Area $\left(\mathrm{m}^{2}\right)$ & $-.424^{* *}$ & 0.002 \\
Abdominal Circumference $(\mathrm{cm})$ & $.298^{*}$ & 0.035 \\
Waist:hip Ratio & $.737^{* *}$ & 0.000 \\
\hline
\end{tabular}

Spearman's rho Test $r$ : Correlation Coefficient ${ }^{*} p<0.01,{ }^{*} p<0.05$

statistically significant positive correlation was determined between weight and the requirement for ephedrine (Table 6) (Figure 3).

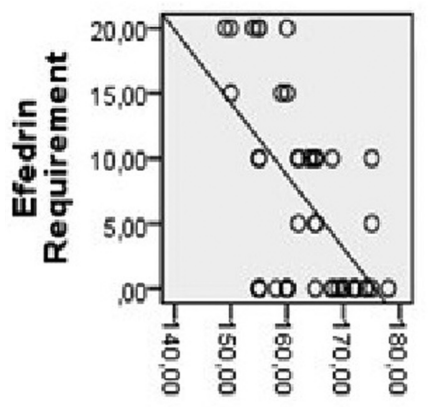

Height

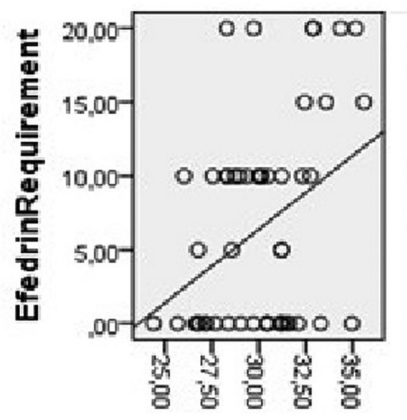

BMI

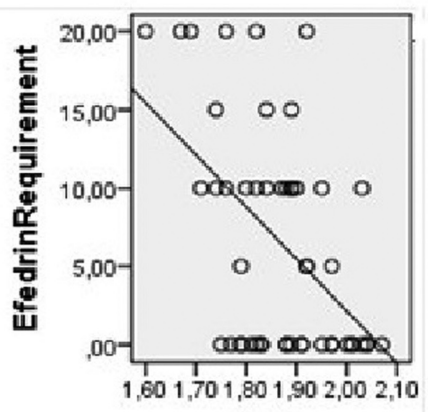

BSA

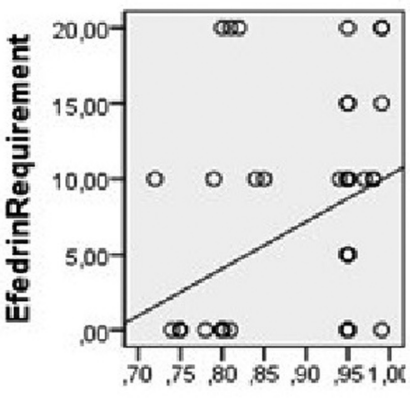

WaistHipRatio

Figure 3. Correlation between anthropometric measurements and the requirement for ephedrine. 
and abdominal circumference.

Within the last 20 years, with the changes in socioeconomic status and nutritional habits in Turkey, just as in developed countries, an increase has been seen in the rates of obesity. The primary reason that obesity is seen more in females is excessive weight gain before and during pregnancy ${ }^{8}$. Therefore, routine monitoring of anthropometric measurements, starting in the antenatal period, is important for the health of both mother and infant to prevent deviations from normal. According to the World Health Organization (WHO) BMI and abdominal obesity classification, BMI of $<18.5 \mathrm{~kg} / \mathrm{m}^{2}$ is accepted as underweight, $18.5-24.9 \mathrm{~kg} / \mathrm{m}^{2}$ as normal, $25.0-29.9 \mathrm{~kg} / \mathrm{m}^{2}$ as slightly overweight, and $>30.0 \mathrm{~kg} / \mathrm{m}^{2}$ as obese; those with a waist:hip ratio of $>0.85$ are classified as abdominally obese ${ }^{9}$. In Turkey, obesity is a serious problem for mothers and potential mothers. According to the 2008 results of the Turkey Population and Health Survey, $58.0 \%$ of the mothers were obese ${ }^{10}$. In investigations conducted in other countries, incidence of slightly overweight/obese pregnant women have varied between $40 \%-50 \% 7$. In the current study, as the mean BMI was $30.1 \pm 2.1 \mathrm{~kg} / \mathrm{m}^{2}$, it was necessary to evaluate the obesity status of the pregnant study participants.

In the evaluation of abdominal obesity, which is a health risk, the waist:hip ratio is accepted as a strong indicator which has reportedly increased in pregnancy because of excessive weight gain ${ }^{9}$. In a previous study of this subject, abdominal obesity was determined in approximately $35.0 \%$ of the pregnant women ${ }^{11}$. It can be said that the waist:hip ratio in females is affected by excessive weight gain in pregnancy ${ }^{12}$. In the current study, the mean waist:hip ratio was determined to be $0.85 \pm 0.21$.

Although not originally morbidly obese, because of the physiological changes which occur antenatally and during birth in pregnant females with BMI of 3035 they should be accepted as morbidly obese ${ }^{13}$. Due to the high risk of maternal morbidity and mortality in general anaesthesia, regional anaesthesia is cur- rently preferred for cases of caesarean section. It is inevitable for sensory block to rise as the result of increased epidural area pressure due to enlarged epidural fat tissue and engorged epidural veins related to obesity ${ }^{4}$. Obstruction of the inferior vena cava by the growing uterus increases epidural blood volume by widening the epidural venous plexus. The volume of spinal cerebrospinal fluid decreases and the potential volume of the epidural space are reduced, resulting in increased distribution of the local anaesthetic solution from the entry area to the upper dermatomes during application of spinal and epidural anaesthesia ${ }^{4}$.

In most studies, a relationship has been determined between increased $\mathrm{BMI}$ and the level of neuraxial anesthesia (spinal or epidural) ${ }^{14,15}$. In addition, the epidural space volume decreases due to fat infiltration, increased blood volume, and increased intraabdominal pressure and, as a result, the requirement for local anaesthetic in obese patients is reduced to $70 \%-80 \%$ of that required by normal weight patients during epidural or spinal anaesthesia ${ }^{14}$.

In the current study, when the correlation was examined between anthropometric measurements and the dermatome site where the maximum sensorial block was formed, it was seen that as BMI and abdominal circumference increased, so the level of spinal anaesthesia was higher. Also, with a decrease in height and waist:hip ratio and increase in BSA, the level of spinal anaesthesia was higher. In light of these data, future studies conducted on a more extensive population could calculate the local anaesthetic dose not generically, but with a safer formula tailored for each patient.

In a case report, a 34-year old morbidly obese, preeclamptic pregnant female was administered epidural block ( $0.5 \%$ bupivacaine $5 \mathrm{ml}$ ) for a caesarean operation and no motor block was observed but the sensory block level reached as far as T4, with a relatively increased response to epidural anesthesia. In that case report, it has been stated that in morbidly obese pregnant patients, anaesthesia should 
be provided with epidural drugs at a partially low volume $^{16}$.

In the current study, a statistically significantly positive correlation was determined between the BSA values and the time taken for the sensorial block to reach T4 dermatome. In tall patients and those with a higher BSA, the time taken for the drug to reach T4 was prolonged and, conversely, in patients with increased abdominal circumference and increased waist:hip ratio, the distribution of the drug to the T4 dermatome was more rapid.

In previous studies, the incidence of hypotension in pregnant patients under spinal anaesthesia has been reported at rates varying from $7 \%-80 \%^{17,18}$. Hypotension may cause fetal pathological bradycardia when maternal blood pressure falls below $100 \mathrm{mmHg}^{19}$. The reasons that studies have shown such a great difference in the incidence of hypotension is the threshold of hypotension used and varying doses of local anaesthetics. In the current study, a fixed dose of spinal anaesthesia was used and the incidence of hypotension was found to be $54 \%$.

In a study which examined the records of 503 cases that had undergone caesarean operation with spinal anaesthesia, hypotension was determined in 56.5\% (284 patients) of the patients after spinal anaesthesia. Researchers have reported maternal age, BMI, body weight, sensory block level, and infant birthweight to be the factors affecting hemodynamic in mothers who are to undergo caesarean surgery with spinal anaesthesia. When age is $\geq 35$ years, BMI $\geq 29 \mathrm{~kg} / \mathrm{m}^{2}$, and sensory block level $\geq T 6$, the risk of hypotension will increase and BMI, age, and sensory block level have been reported to be independent risk factors for hypotension ${ }^{20}$. Similarly, in the current study, in patients with short height, increased abdominal circumference, moderate BSA, and increased waist:hip ratio, the frequency of hypotension was increased. In parallel, hypotension was also seen to be increased when the time taken to reach T4 was short and the dermatome site of the maximum sensorial block was at a high level.
In a study where local anaesthetic was administered to patients at height- and weight-adjusted doses, the conclusion was reached that in comparison to patients given a fixed dose, the rates of hypotension and bradycardia were lower and spinal block was not achieved at a lower level ${ }^{21}$. In the current study, a fixed dose of local anaesthetic was administered and it was determined that in patients with increased $\mathrm{BMI}$, high waist:hip ratio, short height, and large $A C$, there was an increased requirement for ephedrine. In addition to weight, height, and BMI, the other anthropometric parameters examined in this study were found to be related to the level of spinal block.

The application of a large volume of crystalloid 1520 mins before spinal anaesthesia is a widely-used method to prevent hypotension. The aim of this application is to increase venous return, central blood volume, and cardiac output ${ }^{22}$. Since the first study by Wollman and Marx in which it was stated that hypotension could be prevented by rehydration before the application of spinal anaesthesia, many studies have been conducted but with varying results ${ }^{23}$. In the current study, crystalloid infusion was administered to all patients 20 mins before spinal anaesthesia to prevent hypotension.

Bradycardia which develops during spinal anaesthesia is associated with a high level of block due to the blocking of preganglionic accelerator fibers partially emerging from T1-T4. Bradycardia may also create a reduction in the right atrium pressure and in the pressure of the large veins entering the right atrium. The incidence of bradycardia following spinal anaesthesia has been reported as $2.5 \%-13.0 \%^{24,25}$.

In a prospective study that examined the risk factors and side effects associated with spinal anaesthesia in 952 patients, the incidence of bradycardia was reported at $13 \%$. Potential risk factors for the development of bradycardia were defined as baseline heart rate of $<60 / \mathrm{min}$, ASA I physiological score, beta blocker treatment, and sensory block at T5 or over ${ }^{25}$.

In another prospective study of 1220 patients, the 
incidence of bradycardia was reported as $4.9 \%$. In that study, it was concluded that the most significant risk factor for the development of bradycardia was advanced age and analgesia level of T4 and over $^{26}$. In the current study, a fixed dose of spinal anaesthesia was applied and the incidence of bradycardia was found to be $18 \%$. The results of the study showed that short height, high BMI, a moderate BSA, and increased waist:hip ratio were risk factors for bradycardia. An increased incidence of bradycardia was seen in patients where the time to reach T4 was shorter and the level of maximum sensorial block was higher.

In conclusion, in patients for whom spinal anaesthesia is planned, estimates of the spinal anaesthesia sensory block characteristics can be managed in accordance with the values obtained from quick and simple anthropometric measurements. The probability of the development of bradycardia or hypotension can be predicted and better preparations can be made. More extensive future studies would offer the opportunity to create a formula for the amount of local anaesthetic to be used in spinal anaesthesia with the aid of easily performed anthropometric measurements thereby reducing complication rates.

\section{REFERENCES}

1. Santos AC, Fihster M, Pederson H. Obstetric Anesthesia. In: Barash PG, Cullen BF, Stelty RK (Eds.). Clinical Anesthesia. Philadelphia: JP Lippincott Co; 1998. p.1267-1306.

2. Clark SL. Cesarean Section. In: Hankils GDV, Clark SL, Cunnigham FG, Giltstrap LC (Eds.). Operative Obstetrics. Connecticut: Appleton and Lange; 1995. p.301-322.

3. Erdine S. Rejyonel Anestezi. İstanbul: Nobel Matbaacılık, 2005:159-79,253-270.

4. Morgan GE, Mikhail MS, Murray MJ, Larson CP (Çeviri: M Tulunay, H Cuhruk) Klinik Anesteziyoloji. 4. baskı. Ankara: Öncü Matbaası; 2004;263-275,813-815,874-878,901-903.

5. Leddy MA, Power ML, Schulkin J. The impact of maternal obesity on maternal and fetal health. Rev Obstet Gynecol 2008;1:170-8.

6. Persson M, Johansson S, Villamor E, Cnattingius S. Maternal overweight and obesity and risks of severe birth-asphyxiarelated complications in term infants: a population-based cohort study in Sweden. PLoS Med 2014;11:e1001648. http://dx.doi.org/10.1371/journal.pmed.1001648

7. Rees GA, Porter J, Bennett $S$ et al. The validity and reliability of weight and height measurements and body mass index calculations in early pregnancy. J Hum Nutr Diet 2012;25:117-20.

http://dx.doi.org/10.1111/j.1365-277X.2011.01207.x

8. Samur G. Obezite ve gebelik. T.C. Sağlık Bakanlığı Temel Sağlık
Hizmetleri Genel Müdürlüğü Beslenme ve Fiziksel Aktiviteler Daire Başkanlığı, Klasmat Matbaacılık 2008, Ankara. ss:7.

9. Waist circumference and waist-hip ratio: report of a WHO expert consultation, Geneva, 2008.

10. Hacettepe Üniversitesi Nüfus Etütleri Enstitüsü Türkiye Nüfus ve Sağlık Araştırması, 2008.

11. Ebrahimi-Mameghani M, Mehrabi E, Kamalifard M, Yavarikia P. Correlation between body mass index and central adiposity with pregnancy complications in pregnant women. $\mathrm{He}$ alth Promot Perspect 2013;3:73-9.

12. Hodgkinson R, Husain FJ. Obesity and the cephalad spread of analgesia following epidural administration of bupivacaine for cesarian section. Anesth Analg 1980;59:89-92.

13. Hall LF, Neubert AG. Obesity and pregnancy. Obstet Gynecol Surv 2005;60:253-60. http://dx.doi.org/10.1097/01.ogx.0000158509.04154.9e

14. Taivainen T, Tuominen M, Rosenberg PH. Influence of obesity on the spread of spinal analgesia after injection of plain $0.5 \%$ bupivacaine at the L3-4 and the L4-5 interspace. $\mathrm{Br} \mathrm{J}$ Anesth 1990;64:542-6.

15. Santos A, Pedersen H, Finster M, Edström H. Hyperbaric bupivacaine for spinal anesthesia in cesarean section. Anesth Analg 1984;63:1009-1013. http://dx.doi.org/10.1213/00000539-198411000-00009

16. Fidan $\mathrm{H}$, Fenkçi V, Yegit $\mathrm{M}$ et al. Morbid obez sezaryen vakasında anestezi. Kocatepe Tıp Dergisi 2005;6:45-7.

17. Loughrey JP, Walsh F, Gardiner J. Prophylactic intravenous bolus ephedrine for elective Caesarean section under spinal anaesthesia. Eur J Anaesthesiol 2002;19:63-8. http://dx.doi.org/10.1017/S0265021502000108

18. Kararmaz A, Kaya S, Turhanoğlu S, Özyılmaz MA. Sezaryen için spinal anestezi uygulanan vakalarda hipotansiyon ile ilişkili faktörler. Dicle Tıp Dergisi 2003;30:61-5.

19. Dyer RA, Rout CC, Kruger AM et al. Prevention and treatment of cardiovascular instability during spinal anaesthesia for cesarean section. SAMJ 2004;94:367-72.

20. Brenck F, Hartmann B, Katzer C et al. Hypotension after spinal anesthesia for cesarean section: identification of risk factors using an anesthesia information management system. 2009; 23:85-92.

21. Harten JM, Boyne I, Hannah P et al. Effects of a height and weight adjusted dose of local anaesthetic for spinal anaesthesia for elective Caeserean section. Anaesthesia 2005;60:348-53. http://dx.doi.org/10.1111/j.1365-2044.2005.04113.x

22. Mojica JL, Meléndez HJ, Bautista LE. The timing of intravenous crystalloid administration and incidence of cardiovascular side effects during spinal anesthesia: the results from a randomized controlled trial. Anesth Analg 2002;94:432-7.

23. Wollmann SB, Marx GF. Acute hydration for prevention of hypotension of spinal anesthesia in parturients. Anesthesiology 1968;23:74-80.

24. Somboonviboon W, Kyokong O, Charuluxananan S, Narasethakamol A. Incidence and risk factors of hypotension and bradycardia after spinal anesthesia for cesarean section. J Med Assoc Thai 2008;91:181-7.

25. Carpenter RL, Caplan RA, Brown DL et al. Incidence and risk factors for side effects of spinal anesthesia. Anesthesiology 1992;76:906-16. http://dx.doi.org/10.1097/00000542-199206000-00006

26. Kyokong O, Charuluxananan S, Sriprajittichai $P$ et al. The incidence and risk factors of hypotension and bradycardia associated with spinal anesthesia. J Med Assoc Thai 2006;89(Suppl 3):58-64. 